Discourse and Communication for Sustainable Education, vol. 12, no. 2, pp. 108-123, 2021

\title{
Authentic Teaching Tasks for Academic Success, Attitude, Problem Solving, and Creative Thinking Skills
}

\author{
Emine Kübra Pullu \\ Munzur University, Tunceli, Turkey \\ Mehmet Nuri Gömleksiz \\ Fırat University, Elazığ, Turkey
}

\begin{abstract}
This research was prepared in order to determine the change in students' academic achievement, retention levels and attitudes, and problem solving skill and creative thinking skill as a result of programming teaching with authentic task-based applications. The research was prepared using an experimental design with pretest-posttest control group. In the study group of the research, $2^{\text {nd }}$ year Computer Technologies Department students who studied at Erciyes University in the 2017-2018 academic year and took the Web Design Fundamentals course and the Research Methods and Techniques course are included. One of the second-year branches was determined as experimental group $(\mathrm{n}=30)$ and the other one was determined as the control group $(\mathrm{n}=33)$. The teaching of programming to the experimental group students was carried out with authentic tasks. Lessons were conducted with the control group students using the traditional teaching method. Achievement test developed by the researchers as pre-test, post-test, retention test, as well as Attitude Scale Toward Computer Programming developed by Baser (2013), Problem Solving Inventory developed by Heppner and Peterson (1982) and adapted to Turkish by Sahin, Sahin and Heppner (1993), "How Creative Are You?" scale developed by Raudsepp (1977) and adapted to Turkish by Coban (1999) were used. With research, it was concluded that authentic task-oriented practices increased students' programming academic success and attitudes towards programming, and also positively affected both students' problem-solving skills and creative thinking skills.
\end{abstract}

Key words: authentic learning, creative thinking, programming teaching, experimental design, problem solving 


\section{Introduction}

Schooling and education include various and general purposes such as continuous growth and development of the global community, preservation of human values, preserving the quality of life, and increasing productivity and development in educated citizenship (Reed, 2015, p. 11). Today, it seems students are more focused on what they have learned, are more inclined to learn new skills, succeed in different situations and be better prepared to cope with life issues other than the academy (Iucu \& Marin, 2014, p. 410). The main aim of pedagogy is the effective learning and teaching process. Innovations this century are radically transforming our society and the labor market. In the ever-changing globalizing world, it has become a necessity to educate children to be prepared for lifelong learning, to think with sustainability awareness and to be responsible citizens. Sustainability of lifelong learning has gained importance (Hercz, Pozsonyi, \& Flick-Takács, 2020; Heasly et al., 2020). Teaching practices and techniques that have a solid foundation in learning are necessary for sustainable education (Taranto \& Buchanan, 2020). It is a common expectation that students become "real learners" who are able to address hard problems and have the talent to make meaning based on real-world experience (Newmann, Marks, \& Gamoran, 1995, p. 2). Education, transformed from a behavioral framework to a constructivist framework develops between school learning and real life learning and encourages authentic learning congruent with expectations (Herrington \& Oliver, 2000, p. 23). Young (1993, p. 55) said that authentic activities will cause significant changes in the future of education. Authentic learning has brought a new dimension to teaching design since it emphasizes perception and activities rather than memorization and recall.

For the concept of authentic learning, we first look at the word authentic. Newmann, Marks and Gamoran (1996) declare the term of authentic as commonly a real thing rather than something artificial or specious. Borthwick, Bennett, Lefoe and Huber (2007, p. 17) expressed the concept of authentic learning as a method encouraging the students' desire to continue learning beyond the classroom by easing the learning of the discipline thereby establishing connections within themselves. Authentic learning is composed of the intersection of workplace information problems, personal information needs and academic information problems and tasks (Callison \& Lamb, 2004). When looking at authentic learning as a starting point, this term 'authentic learning' is relatively new; however, it goes back to previous years as the learning idea in the context of introducing real-world applications of information (Rule, 2006, p. 1).

In general, a program signifies a solution which is obtained by using programming language and meets a requirement by combining algorithm or algorithms which express the work, which will solve a problem, as step-by-step introduction of basic commands and expressions. Realizing an IT-based automation by bringing programs together is called software (Arsan \& Çölkesen, 2012, p. 59). Programming language is specific applications by which program can be written (Yaşar, 2012, p. 2). Programming language, which is a tool establishing communication with the programmer and computer, is a set of rules used in writing programs (Vatansever, 2007, p. 14). Learning programming consists of four stages: analyzing the problem, designing and developing algorithms, applying the algorithm, and testing and revising the algorithm. These four stages of the software life cycle include constructing information (Garner, 2003, p. 214). Programming is a very complex topic requiring efforts and special approach in order to learn and teach. 
Since students have to understand and apply intangible concepts while learning programming, they start with creating algorithms that solve concrete problems as the first stage. In this first stage, it is important to develop skills specific to programming but equally to develop and integrate the general problem solving and logical reasoning skills that students have acquired in previous years (Gomes \& Mendes, 2007). In the business world, creativity and problem solving by exactly identifying the problem is regarded as equivalent and important (Robinson, 2003, p. 134).

Authentic learning is one of the learning methods that provide increasing creative thinking and problem solving skills. Unlike traditional applications, authentic learning involves finding and focusing on a problem, determining the relevant information, categorizing that information and analyzing content critically, then synthesizing these analysis results with a creative effort (Renzulli, Gentry, \& Reis, 2004). The students' confidence in having skills to understand complex subjects, thereby developing new and unique solutions to problems with critical and creative thinking skills, appreciating ideas and opinions of other students, and benefitting from them is fundamentl to the authentic learning concept, that develops metacognition and thinking skills of students engaging them in the work of professionals (Rule, 2006; Gatlin \& Edwards, 2007). Authentic task-oriented practices permit students to attend actively in the education process and transfer what they have learned to real-life situations. Thus, they increase their ability to produce different solutions to real life problems. In the authentic learning approach, students address more than one task, create new ideas and critically evaluate information and use high-level thinking skills (Gleeson, 2011, p. 36; Gündoğan \& Gültekin, 2018, p. 804). Authentic missions also serve sustainable pedagogy. Sustainable education, which includes creating and maintaining a professional community, is based on the basic concepts of creativity. Sustainable pedagogy encourages risk taking, develops creative thinking and supports the establishment of a collaborative learning culture (White, 2008). The key point and change agent in sustainable education is one's own teacher (Tillmanns, Holland, \& Filho, 2017).

\section{Methodology}

This study aimed to determine the effect of authentic task practices used in programming teaching on students' academic achievement and students' attitudes, and their problem solving skill and creative thinking skill. The research was prepared by using an experimental design with pretest and posttest control group, which shows the participants in different categories as the groups and the measurements are repeated before and after the application (Büyüköztürk, 2016, pp. 5-19).

\section{Sample Group}

The study group occur of $2^{\text {nd }}$ year Computer Technologies Department students who studied at Erciyes University in the 2017-2018 academic year and took the Web Design Fundamentals and Research Methods and Techniques course. While one class was determined as the experimental group, the other class was determined as the control group. The sample group was created by using purposive sampling method in the research. In the purposeful sampling method, the researcher forms the sample group by selecting the participants carrying the desired characteristics using the previous knowledge 
and skills and adds the most appropriate ones to the sample group by using his/her own judgement (Balci, 2006, p. 90).

\section{Formation of Groups}

Groups were formed according to some criteria in accordance with impartiality. This is because there are some points to be considered in the experimental group. In determining the effect of independent variables on dependent variables, groups should be balanced by controlling unwanted surprising variables (Sönmez \& Alacapınar, 2014, p. 52). These criteria were students' grade point averages from $1^{\text {st }}$ Year Programming Basics course, students' $1^{\text {st }}$ year grade point averages, and students' pretest scores. The data were collected according to the criteria determined to ensure non-bias and these data were evaluated according to cluster analysis method. Collecting the individuals who are similar to each other in the same groups was used in cluster analysis. The groups were expected to be homogeneous in themselves and heterogeneous compared to each other (Giray, 2016, p. 14; Uçar, 2008, p. 349; Çakmak, 1999, p. 189). By conducting cluster analysis according to K-Means technique, the sample group was determined with a total of 63 students in dual assignment. While 30 students are in the experimental group, 33 students are in the control group. Firstly, Shapiro-Wilk test was conducted to determine whether or not the groups were normally distributed and it was confirmed that the students' $1^{\text {st }}$ Year Programming Basics course grade point averages, $1^{\text {st }}$ Year grade point averages and pretest scores met the normality assumption, i.e., they showed normal distribution. It was idenified that there was not significantly different between the students' $1^{\text {st }}$ Year Programming Basics course grade point averages $\left(t_{(61)}=-0.78\right.$; $\mathrm{p}>0.05), 1^{\text {st }}$ Year grade point averages $(\mathrm{U}=370.000 ; \mathrm{p}>0.05)$ and pretest scores $\left(t_{(61)}=1.577 ; \mathrm{p}>0.05\right)$. The results show that the groups were formed in an unbiased manner.

\section{Data Collection Tools}

In the study, data were collected using 4 different data collection tools. An achievement test of 32 questions has been prepared to be used within the scope of Basics of Web Design Course. The prepared achievement test was applied to 171 students who previously took the Basics of Web Design course and Research Methods and Techniques course for the validity and reliability processes. Four questions with an item discrimination power index below 0.19 were excluded from the test. The final version of the achievement test consisted of 28 questionsThe average power of the test was determined as 0.46 and the KR-20 value was determined as 0.81 . In the study, "Attitude Scale Toward Computer Programming" developed by Baser (2013) was used. The scale consists of four subscales and 38 items. The Cronbach- $\alpha$ reliability coefficients were determined as 0.953 for the overall scale and as $0.944,0.920,0.926$ and 0.618 , respectively for the subscales. The Problem Solving Inventory developed by Heppner and Peterson (1982) and adapted into Turkish by Şahin, Şahin and Heppner (1993) was used. The 6-point Likert-type inventory contain of 35 items. The Cronbach- $\alpha$ reliability coefficient is 0.88 . "How creative are you?" scale was used. The scale was developed by Raudsepp (1977). It was adapted into Turkish by Çoban (1999). The scale, which consists of 50 items and is a 5 point Likert type, has a Cronbach-á coefficient of 0.95 . 


\section{Operations Applied in Research Process}

Authentic task-oriented practices were carried out in the lessons to the students.of the experimental group. Lessons were conducted in the traditional method with the control group' students. Before the application, the stages of forming groups, preparing the achievement test, applying pilot study, conducting the validity and reliability studies and applying pretests were realized. In the application stage, five groups including six students in each were formed from the experimental group in the first week. By conducting necessary conversations and brainstorming, it was decided to design an educational website for preschool children. In the second week, the experimental group students and stakeholders first came together. For this purpose, the groups went to different preschool institutions. The students examined and analyzed the existing educational web pages for preschool children in order to support the identified needs and compared them with their own needs and expectation lists. In the third week, a drama activity was made within 40 minutes. This activity was carried out with a drama expert. In the drama activity, the aim was to understand the preschool children, who are the main stakeholders to use the web page to be prepared by the students, think like them, and develop necessary empathy skills. In the fourth week, the students started their designs and coding by determining the details of the students' designs whose main frame was formed by them. During the course, educational web pages and videos about coding were watched. In the fifth week, the students first made a code writing activity with a software development group located in the technopark to gain real experiences for their projects focusing on real life problems. The students met with the professional software developers in a real work environment on the day and time determined by the researcher and conducted a code writing activity. In the sixth week, the students interviewed staff of a software company, opened by a former student who graduated from their schools in past years. Interviews about customer expectations led to an organized code writing activity with the software developers in the software company. In the seventh week, the students continued their real work experiences and organized a code writing training and interview with Computer Engineering. In the eight week, the students completed and presented their projects. After the application, posttests and retention test were applied.

\section{Data Analysis}

Data were analyzed at SPSS 21. In the evaluation of personal information of the students in the groups, percentage and frequency values were used. After the preliminary application of the achievement test, preliminary analyses were performed by using item difficulty index, item discrimination index, item test difficulty, arithmetic mean, variance, standard deviation, reliability coefficient and KR-20 calculations. Cluster analysis was performed by collecting the data according to the determined criteria and conducting dual assignment according to K-Means technique to ensure non-bias in the formation of groups. In the study, for the scores of the groups from the achievement test, Attitude Scale Toward Computer Programming, problem solving inventory and how creative are you? scale, first the normal distribution of the scores was tested using Shapiro-Wilk test. While parametric tests were used if the data were normally distributed, nonparametric tests were used if they did not show normal distribution. Independent and 
dependent samples t-test were used for parametric tests. Mann-Whitney U (MWU) and Wilcoxon signed-rank tests were used in non-parametric tests.

\section{Findings}

The results obtained from the achievement test, the attitude scale toward computer programming, problem solving inventory and how creative are you? scale and the interpretation of these results are given in this section.

\section{Table 1}

Dependent Sample T-test for the Pretest-Posttest Scores of the Groups From the Achievement Test

\begin{tabular}{llcccccc}
\hline & & $\mathrm{n}$ & $\overline{\mathrm{X}}$ & $\mathrm{sd}$ & $\mathrm{df}$ & $\mathrm{t}$ & $\mathrm{p}$ \\
\hline Experimental group & Pretest & 30 & 4.37 & 1.77 & \multirow{2}{*}{29} & -33.345 & \multirow{2}{*}{$0.000^{*}$} \\
& Posttest & 30 & 22.27 & 2.65 & & & \\
Control group & Pretest & 33 & 3.73 & 1.44 & \multirow{2}{*}{32} & -20.794 & $0.000^{*}$ \\
& Posttest & 33 & 18.39 & 3.54 & & & \\
\hline
\end{tabular}

$* \mathrm{p}<0.05$

It was observed as a result of the dependent samples t-test that the pretest $(\overline{\mathrm{X}}=4.37)$ and posttest $(\overline{\mathrm{X}}=22.27)$ mean scores of the experimental group' students differed statistically significantly in favor of the posttest $[\mathrm{t}(29)=-33.345 ; \mathrm{p}<0.05]$ and the pretest $(\overline{\mathrm{X}}=3.73)$ and posttest $(\overline{\mathrm{X}}=18.39)$ mean scores of the control group' students statistically significantly differed in favor of the posttest $[\mathrm{t}(32)=-20.794 ; \mathrm{p}<0.05]$.

\section{Table 2}

Independent Sample T-test for the Post-test and Retention Scores of the Groups From the Achievement Test

\begin{tabular}{|c|c|c|c|c|c|c|c|c|c|}
\hline & \multirow{2}{*}{ Groups } & \multirow{2}{*}{$\mathrm{n}$} & \multirow{2}{*}{$\overline{\mathrm{X}}$} & \multirow{2}{*}{ sd } & \multirow{2}{*}{$\mathrm{df}$} & \multicolumn{2}{|c|}{ Levene } & \multirow{2}{*}{$\mathrm{t}$} & \multirow{2}{*}{$\mathrm{p}$} \\
\hline & & & & & & $\mathrm{f}$ & $\mathrm{p}$ & & \\
\hline \multirow[t]{2}{*}{ Post-test } & Experimental & 30 & 22.27 & 2.65 & \multirow{2}{*}{61} & \multirow{2}{*}{1.770} & \multirow{2}{*}{0.188} & \multirow{2}{*}{4.872} & \multirow{2}{*}{$0.000 *$} \\
\hline & Control & 33 & 18.39 & 3.54 & & & & & \\
\hline \multirow[t]{2}{*}{ Retention test } & Experimental & 30 & 21.53 & 3.26 & \multirow{2}{*}{61} & \multirow{2}{*}{0.021} & \multirow{2}{*}{0.886} & \multirow{2}{*}{4.972} & \multirow{2}{*}{$0.000 *$} \\
\hline & Control & 33 & 17.18 & 3.65 & & & & & \\
\hline
\end{tabular}

$* \mathrm{p}<0.05$

The students' posttest scores $[\mathrm{t}(61)=4.872, \mathrm{p}<0.05]$ and retention scores $[\mathrm{t}(61)=$ $4.972, \mathrm{p}<0.05$ ] groups differed statistically significantly. It was observed that the posttest mean scores the experimental group' students $(\overline{\mathrm{X}}=22.27)$ were higher than those the control group' students $(\overline{\mathrm{X}}=18.39)$. Similarly retention mean scores the experimental group' students $(\overline{\mathrm{X}}=21.53)$ were higher than the retention mean scores the control group' students $(\overline{\mathrm{X}}=17.18)$. It can be expressibled that there was an increase in success in both groups, but authentic task-oriented applications were more effective in programming teaching than conventional methods. Authentic task-oriented application was more permanent in programming teaching than the traditional method. 


\section{Table 3}

Dependent Sample T-test for the Pre-attitude and Post-attitude Scores of the Attitudes Towards Computer Programming Scale' Sub-dimensions of the Groups

\begin{tabular}{|c|c|c|c|c|c|c|c|}
\hline Sub-dimensions & Groups & $\mathrm{n}$ & $\overline{\mathrm{X}}$ & sd & $\mathrm{df}$ & $\mathrm{t}$ & $\mathrm{p}$ \\
\hline \multirow{6}{*}{$\begin{array}{l}\text { Self-confidence } \\
\text { and motivation }\end{array}$} & Experimental group & & & & \multirow{4}{*}{29} & \multirow{4}{*}{-4.427} & \multirow{4}{*}{$0.000 *$} \\
\hline & Pre-attitude & 30 & 3.11 & 0.55 & & & \\
\hline & Post-attitude & 30 & 3.75 & 0.75 & & & \\
\hline & Control group & & & & & & \\
\hline & Pre-attitude & 33 & 3.03 & 0.46 & \multirow{2}{*}{32} & \multirow{2}{*}{-1.751} & \multirow{2}{*}{0.090} \\
\hline & Post-attitude & 33 & 3.28 & 0.59 & & & \\
\hline \multirow{3}{*}{$\begin{array}{l}\text { Usefulness of } \\
\text { computer } \\
\text { programming }\end{array}$} & Control group & & & & \multirow{3}{*}{32} & & \multirow{3}{*}{$0.004 *$} \\
\hline & Pre-attitude & 33 & 3.10 & 0.39 & & \multirow{2}{*}{-3.133} & \\
\hline & Post-attitude & 33 & 3.58 & 0.65 & & & \\
\hline \multirow{3}{*}{$\begin{array}{l}\text { Attitude toward } \\
\text { success }\end{array}$} & Control group & & & & & & \multirow{3}{*}{$0.000 *$} \\
\hline & Pre-attitude & 33 & 2.95 & 0.50 & \multirow{2}{*}{32} & \multirow{2}{*}{-5.224} & \\
\hline & Post-attitude & 33 & 3.86 & 0.74 & & & \\
\hline \multirow{6}{*}{$\begin{array}{l}\text { Social perception } \\
\text { of success }\end{array}$} & Experimental group & & & & \multirow{4}{*}{29} & \multirow{4}{*}{-9.340} & \multirow{4}{*}{$0.000 *$} \\
\hline & Pre-attitude & 33 & 2.90 & 0.57 & & & \\
\hline & Post-attitude & 33 & 4.47 & 0.52 & & & \\
\hline & Control group & & & & & & \\
\hline & Pre-attitude & 33 & 2.86 & 0.62 & \multirow{2}{*}{32} & \multirow{2}{*}{-2.426} & \multirow{2}{*}{$0.021 *$} \\
\hline & Post-attitude & 33 & 3.45 & 1.25 & & & \\
\hline
\end{tabular}

The dependent samples t-test revealed for self-confidence and motivation subdimension that pre-attitude $(\overline{\mathrm{X}}=3.11)$ and post-attitude $(\overline{\mathrm{X}}=3.75)$ mean scores the experimental group' students differed statistically significantly in favor of the postattitude $[\mathrm{t}(29)=-4.427 ; \mathrm{p}<0.05]$. Likewise, it was observed that the pre-attitude $(\overline{\mathrm{X}}=$ $3.03)$ and post-attitude $(\overline{\mathrm{X}}=3.28)$ mean scores the control group' students differed statistically significantly in favor of post-attitude $[\mathrm{t}(32)=-1.751 ; \mathrm{p}<0.05]$. Usefulness of computer programming sub-dimension results, it was observed that the pre-attitude $(\overline{\mathrm{X}}=3.10)$ and post-attitude $(\overline{\mathrm{X}}=3.58)$ mean scores of the control group' students statistically significantly differed in favor of post-attitude $[t(32)=-3.133 ; p<0.05]$. Similarly It was observed that the pre-attitude $(\overline{\mathrm{X}}=2.95)$ and post-attitude $(\overline{\mathrm{X}}=3.86)$ mean scores of the control group' students for attitude toward success sub-dimension statistically significantly differed in favor of post-attitude $[\mathrm{t}(32)=-5.224 ; \mathrm{p}<0.05]$. It was observed that pre-attitude $(\bar{X}=2.90)$ and post-attitude $(\bar{X}=4.47)$ mean scores the experimental group' students social perception of success sub-dimension differed statistically significantly in favor of the post-attitude $[\mathrm{t}(29)=-9.340 ; \mathrm{p}<0.05]$. Likewise, it was observed that the pre-attitude $(\overline{\mathrm{X}}=2.86)$ and post-attitude $(\overline{\mathrm{X}}=3.45)$ mean scores the control group' students differed statistically significantly in favor of post-attitude $[\mathrm{t}(32)=-2.426$; $\mathrm{p}<0.05]$. 


\section{Table 4}

Wilcoxon Signed-ranks Test for Pre-attitude and Post-attitude Scores of the Attitudes Towards Computer Programming Scale' Sub-dimensions of the Groups

\begin{tabular}{lllccccc}
\hline Sub-dimensions & Groups & $\begin{array}{l}\text { Pre-attitude }- \\
\text { Post-attitude }\end{array}$ & $\mathrm{n}$ & $\begin{array}{c}\text { Mean } \\
\text { rank }\end{array}$ & $\begin{array}{c}\text { Sum of } \\
\text { ranks }\end{array}$ & $\mathrm{z}$ & $\mathrm{p}$ \\
\hline Usefulness of & Experimental & Negative ranks & 2 & 5.50 & 11.00 & & \\
computer & group & Positive ranks & 28 & 16.21 & 454.00 & -4.558 & $0.000^{*}$ \\
programming & & Ties & 0 & & & & \\
& & Total & 30 & & & & \\
Attitude toward & Experimental & Negative ranks & 0 & 5.50 & 11.00 & & \\
success & group & Positive ranks & 30 & 15.50 & 465.00 & -4.784 & 0.000 \\
& & Ties & 0 & & & & \\
& & Total & 30 & & & & \\
\hline
\end{tabular}

$* \mathrm{p}<0.05$

Wilcoxon signed rank test revealed for usefulness of computer programming subdimension that there was a statistically significant difference between the pre-attitude and post-attitude scores the experimental group' students $[Z=-4.558, p=.001]$. Similarly for attitude toward success sub-dimension a significant difference was noted between the pre-attitude and post-attitude scores of the experimental group' students. $[Z=-4.78$, $\mathrm{p}=.000]$. The significant difference found the experimental group' students was in favor of the students' post-attitude scores.

Table 5

MWU Test on the Post-attitude Scores of the Groups in the Subscales

\begin{tabular}{llccccc}
\hline & Groups & $\mathrm{n}$ & Mean rank & Sum of ranks & MWU & $\mathrm{p}$ \\
\hline Self-confidence & Experimental & 30 & 37.73 & 1132.00 & \multirow{2}{*}{323.000} & $0.018^{*}$ \\
and motivation & Control & 33 & 26.79 & 884.00 & & \\
$\begin{array}{l}\text { Usefulness of } \\
\text { computer }\end{array}$ & Experimental & 30 & 39.52 & 1185.50 & 269.500 & $0.002 *$ \\
programming & Control & 33 & 25.17 & 830.50 & & \\
$\begin{array}{l}\text { Attitude toward } \\
\text { success }\end{array}$ & Experimental & 30 & 41.75 & 1252.50 & 202.500 & $0.000^{*}$ \\
Social perception & Control & 33 & 23.14 & 763.50 & & \\
of success & Experimental & 30 & 40.80 & 1224.00 & 213.000 & $0.000^{*}$ \\
\hline
\end{tabular}

$* \mathrm{p}<0.05$

There was a statistically significant difference in self-confidence and motivation in computer programming subscale $(\mathrm{U}=323.000 ; \mathrm{p}<0.05)$, usefulness of computer programming subscale $(\mathrm{U}=269.000 ; \mathrm{p}<0.05)$, attitude toward success in computer programming subscale $(\mathrm{U}=202.500 ; \mathrm{p}<0.05)$ and social perception of success in computer programming subscale $(\mathrm{U}=202.500 ; \mathrm{p}<0.05)$. When the mean rank in all four subscales was examined, it was concluded that the mean rank the experimental group' students was higher than the mean rank the control' students group. This result can be 
interpreted as follows: the use of authentic task-oriented applications in the programming teaching had a positive effect on the students' attitude towards self-confidence and motivation in programming course, attitudes towards the usefulness of the programming, attitudes toward success in programming and social perception of success in programming.

\section{Table 6}

Dependent Sample T-test for the Pre-attitude and Post-attitude Scores of the Attitudes Towards Computer Programming Scale of the Groups

\begin{tabular}{llcccccc}
\hline & & $\mathrm{n}$ & $\overline{\mathrm{X}}$ & $\mathrm{sd}$ & $\mathrm{df}$ & $\mathrm{t}$ & $\mathrm{p}$ \\
\hline Experimental group & Pre-attitude & 30 & 3.06 & 0.37 & \multirow{2}{*}{29} & -7.991 & \multirow{2}{*}{0.000} \\
& Post-attitude & 30 & 4.11 & 0.66 & & & \\
Control group & Pre-attitude & 33 & 3.02 & 0.34 & \multirow{2}{*}{32} & -3.495 & 0.001 \\
& Post-attitude & 33 & 3.50 & 0.58 & & & \\
\hline
\end{tabular}

$* \mathrm{p}<0.05$

It was determined that the pre-attitude $(\overline{\mathrm{X}}=3.06)$ and post-attitude $(\overline{\mathrm{X}}=4.11)$ mean scores the experimental group' students differed statistically significantly in favor of post-attitude $[\mathrm{t}(29)=-7.991 ; \mathrm{p}<0.05]$. Likewise, it was observed that the pre-attitude $(\overline{\mathrm{X}}=3.02)$ and post-attitude $(\overline{\mathrm{X}}=3.50)$ mean scores the control group' students differed statistically significantly in favor of the post-attitude [ $t(32)=-3.495 ; \mathrm{p}<0.05]$.

\section{Table 7}

Independent Samples T-test for the Post-attitude Scores From the Groups' Attitude Scale Towards Computer Programming

\begin{tabular}{lcccccccc}
\hline \multicolumn{1}{c}{ Groups } & $\mathrm{n}$ & $\overline{\mathrm{X}}$ & $\mathrm{sd}$ & $\mathrm{df}$ & \multicolumn{2}{c}{ Levene } & \multirow{2}{*}{$\mathrm{t}$} & $\mathrm{p}$ \\
\cline { 1 - 3 } & & & & & $\mathrm{f}$ & $\mathrm{p}$ & & \\
Experimental & 30 & 4.11 & 0.66 & 61 & 0.299 & 0.586 & \multirow{2}{*}{3.914} & $0.000^{*}$ \\
Control & 33 & 3.50 & 0.58 & & & & & \\
\hline
\end{tabular}

$* \mathrm{p}<0.05$

The post-attitude scores of the students in the groups differed statistically significantly $[\mathrm{t}(61)=3.914, \mathrm{p}<0.05]$. It was seen that the post-attitude mean scores of the experimental group' students $(\overline{\mathrm{X}}=4.11)$ were higher than the post-attitude mean scores of the control group' students $(\overline{\mathrm{X}}=3.50)$. This result can be expressed as the fact that the use of authentic task-oriented applications in programming teaching had a positive impact on the students' attitudes toward computer programming. 


\section{Table 8}

Dependent Sample T-test for the Pretest and Posttest Scores Taken From the Problem Solving Inventory and Pre-attitude and Post-attitude Scores Taken From the "How Creative are You?" Scale of the Groups

\begin{tabular}{llcccccc}
\hline & $\mathrm{n}$ & $\overline{\mathrm{X}}$ & $\mathrm{sd}$ & $\mathrm{df}$ & $\mathrm{t}$ & $\mathrm{p}$ \\
\hline $\begin{array}{l}\text { Problem solving } \\
\text { inventory }\end{array}$ & $\begin{array}{l}\text { Experimental group } \\
\text { Pretest }\end{array}$ & 30 & 85.83 & 14.62 & 29 & -9.740 & $0.000^{*}$ \\
& $\begin{array}{l}\text { Posttest } \\
\text { Control group }\end{array}$ & 30 & 132.70 & 18.83 & & & \\
& $\begin{array}{l}\text { Pretest } \\
\text { Posttest }\end{array}$ & 33 & 87.39 & 12.40 & 32 & -8.189 & $0.000^{*}$ \\
"How creative & Experimental group & & 119.52 & 16.04 & & & \\
are you?" scale & $\begin{array}{l}\text { Pre-attitude } \\
\text { Post-attitude }\end{array}$ & 30 & 20.90 & 13.63 & 29 & -8.385 & $0.000^{*}$ \\
& $\begin{array}{l}\text { Control group } \\
\text { Pre-attitude }\end{array}$ & 33 & 44.83 & 6.80 & & & \\
& Post-attitude & 33 & 24.39 & 13.04 & 32 & -5.262 & $0.000^{*}$ \\
\hline
\end{tabular}

$* \mathrm{p}<0.05$

For problem solving inventory pretest $(\overline{\mathrm{X}}=85.83)$ and posttest $(\overline{\mathrm{X}}=132.70)$ mean scores the experimental group' students differed statistically significantly in favor of the post-test $[\mathrm{t}(29)=-9.740 ; \mathrm{p}<0.05]$. Likewise, it was observed that the pretest $(\overline{\mathrm{X}}=87.39)$ and posttest $(\overline{\mathrm{X}}=119.5)$ mean scores the control group' students differed statistically significantly in favor of the posttest $[\mathrm{t}(32)=-8.189 ; \mathrm{p}<0.05]$. How creative are you? scale show that pre-attitude $(\bar{X}=20.90)$ and post-attitude $(\bar{X}=44.83)$ mean scores the experimental group' students differed statistically significantly in favor of the posttest $[\mathrm{t}(29)=-8.385 ; \mathrm{p}<0.05]$. Likewise, pre-attitude $(\overline{\mathrm{X}}=17.48)$ and post-attitude $(\overline{\mathrm{X}}=24.39)$ mean scores the control group' students differed statistically, significantly in favor of the posttest $[\mathrm{t}(32)=-5.262 ; \mathrm{p}<0.05]$. The creativity level is evaluated as high if the students' scale scores are between 100 and 80, as above average if they are between 79 and 60, as average if they are between 59 and 40, as below average if they are between 39 and -20 and finally if they are between -19 and -100 , then they are evaluated as noncreative. When the pre-attitude scores of the groups' students were examined, the creativity levels of both groups were observed to be below average. However, in terms of postattitude scores, the creativity levels of the students in the control group were still below average; on the other hand, the creativity levels the experimental groups' students were average. 


\section{Table 9}

Independent Sample T-test for the Post-test Scores Obtained by the Groups From the Problem-solving Inventory

\begin{tabular}{lcccccccc}
\hline \multicolumn{1}{c}{ Groups } & $\mathrm{n}$ & $\overline{\mathrm{X}}$ & $\mathrm{sd}$ & $\mathrm{df}$ & \multicolumn{2}{c}{ Levene } & \multirow{2}{*}{$\mathrm{t}$} & $\mathrm{p}$ \\
\cline { 1 - 3 } $\begin{array}{l}\text { Experimental } \\
\text { Control }\end{array}$ & 30 & 132.70 & 18.83 & 61 & 0.316 & 0.576 & \multirow{2}{*}{3.000} & $0.004 *$ \\
\hline
\end{tabular}

$* \mathrm{p}<0.05$

Posttest scores of the students in the groups differed statistically, significantly in favor of posttest $[\mathrm{t}(61)=3.000 . \mathrm{p}<0.05]$. Posttest mean scores the experimental group' students $(\overline{\mathrm{X}}=132.70)$ was higher than the posttest mean scores the control group' students $(\overline{\mathrm{X}}=119.52)$. According to this result, it can be interpreted as the fact that the use of authentic task-oriented applications in programming teaching had a positive impact on the problem solving skills of the students.

\section{Table 10}

MWU Test Related to How Creative are You? Scale Post-attitude Scores of the Groups

\begin{tabular}{lccccc}
\hline Groups & $\mathrm{n}$ & Mean rank & Sum of ranks & MWU & $\mathrm{p}$ \\
\hline Experimental & 30 & 46.12 & 1383.50 & 71.500 & \\
Control & 33 & 19.17 & 632.50 & & $0.000^{*}$ \\
\hline
\end{tabular}

$* \mathrm{p}<0.05$

There was a statistically significant difference $(U=71.500 ; \mathrm{p}<0.05)$. When the mean rank results were determined, it was observed that the mean rank of the experimental group' students $(\mathrm{SO}=46.12)$ was higher than the mean rank of the control group' students $(\mathrm{SO}=19.17)$. This result can be interpreted as the fact that the use of authentic task-oriented applications in programming teaching had a positive impact on creativity levels of the students.

\section{Discussion}

In the study, authentic task-oriented applications were compared with traditional method for programming teaching. In research, authentic task-oriented applications in programming teaching increased the students' academic achievement and the retention level of the students in learning more. When the studies were examined, Purcell-Gates, Duke and Martineau (2011) concluded in their study that there was a positive energy between authentic-based activities and success, and these activities increased the success. Besides, Mintah (2009) and Dennis and O'Hair (2010) determined that authentic learning environments and processes increased the students' academic success. Koçyiğit (2011), Koçyiğit and Zembat (2013) found in their study using authentic tasks that these tasks increased academic successes of university students more than the students using traditional method. In addition, Niesz (2003) determined that authentic learning environment and authentic projects increased academic successes of the students, Johnson (2007) 
specified that authentic learning and evaluation experiences increase students' academic successes and Hussain, Ahmad, and Khan (2015) found that authentic applications increased the students' academic successes and students' retention levels in learning.

It has been observed that the use of authentic task-oriented practices in programming teaching increases students' self-confidence, positively affects their motivation and enables them to develop more positive attitudes towards success. Kinay and Bağçeci (2015) concluded in their study that university students had more positive beliefs towards learning with authentic activities and applications compared to the traditional method. Likewise, Aydın-Assk (2016) concluded that the self-confidence of the students toward the course increased through authentic task-oriented applications. It was observed as a result of the statistical analyses conducted with respect to the overall scale with the subscales, that the use of authentic task-oriented applications in programming teaching developed more positive attitudes in students towards programming compared to the traditional method. When similar studies were examined, Koçyiğit (2011) found in his study, in which authentic tasks were used, that university students' attitudes toward the course increased more compared to the students using traditional method. Similarly, Horzum and Bektaş (2012) found that authentic task-oriented activities increased the attitudes and motivations of university students toward the course.

In addition it was appeared that the use of authentic task-oriented applications in programming teaching had more positive effects on students' problem solving and creativity levels compared to traditional methods. Goold and Rimmer (2000) stated that problem solving skills had a important effect on the university performances in programming courses of students. Calder (2010) found in his studies that programming education improved the students' problem solving processes and has a significant effect on increasing problem solving skills. Grover, Pea and Cooper (2015) determined in their study that students' problem solving skills also improved along with programming teaching and algorithmic thinking skills. Creativity is very important as a component of students' behavior in general. A creative individual also has problem-solving skills (Slahova, Volonte, \& Cacka, 2017). Authentic learning gives students the opportunity to develop their creative thinking (Göçmen, 2004, p. 7). Caseley (2004) and Preus (2012) concluded in their study that students can develop high-level thinking skills through authentic learning. High-level thinking skills in the context of authentic learning enable students to discover new meanings and insights (Newmann \& Wehlage, 1993, p. 8-11). Thus, it can be asserted that creative thinking skills of individuals improved with authentic learning.

\section{Conclusion}

In the study, authentic task-oriented applications were compared with traditional method in programming teaching after 8-week application process. In order to gain real life experiences with the experimental group students, different authentic tasks were practised every week. With the control group students, the lessons were taught with the traditional method and no extra application was made. As a result of the research both authentic task-oriented applications and traditional applications used in programming teaching were found to have positive effects. However, it was concluded that the programming teaching made with authentic task-oriented applications was more effective 
than the programming teaching made with traditional method. This result showed that the use of authentic task-oriented applications was more effective in programming teaching and increasing academic success.

When the findings related to the attitude scale towards computer programming are examined, the use of authentic task-oriented applications in programming teaching was observed to increase students' self-confidence and to have positive effects on their motivation. In addition, these applications helped students to have more positive attitudes about the benefit of programming and being successful. Besides, being successful in programming affected the students' attitudes positively in terms of social perception.

Statistical analyses show that on problem solving inventory, it was noted that the use of authentic task-oriented applications in programming teaching had more positive effects on students' problem solving skills compared to traditional methods. Similarly for the creativity scale, it appeared that the use of authentic task-oriented applications in programming teaching had more positive effects on the students' creativity levels compared to the traditional methods.

Note:

(1) This study was derived from the doctoral dissertation under supervision of Prof. Dr. Mehmet Nuri Gömleksiz at Fırat University.

\section{References}

Arsan, T., \& Çölkesen, R. (2012). Algoritma ve akış şemalan [Algorithm and flowcharts], R. Çölkesen (Ed.). Bilgisayar mühendisliğine giriş temelleri [Introductory basics in computer engineering] (pp. 57-76). İstanbul, Papatya Publisher.

Aydın-Aşk, Z. (2016). Matematik dersinde otantik görev odakl öğrenme süreçlerinin incelenmesi: bir eylem araşttrmast [The study of authent $\mathrm{c}$ task focused learning process in the maths course: An action research]. Yayımlanmamış Doktora Tezi, Gaziantep Üniversitesi Eğitim Bilimleri Enstitüsü, Gaziantep.

Balc1, A. (2006). Sosyal bilimlerde araştırma: yöntem, teknik ve ilkeler [Research in social sciences: Methods, techniques and principles]. Ankara, PegemA Publisher.

Başer, M. (2013). Bilgisayar programlamaya karşi tutum ölçeği geliştirme çalişmasi [Developing attitude scale toward computer programming]. The Journal of Academic Social Science Studies, 6(6), 199-215.

Büyüköztürk, Ş. (2016). Deneysel desenler (5. Baskı) [Experimental patterns]. Ankara, PegemA Publisher.

Callison, D., \& Lamb, A. (2004). Key words in instruction: Authentic learning. School Library Media Activities Monthly, 21(2), 34-39.

Caseley, P. M. (2004). Toward an authentic pedagogy: An investigation of authentic learning instruction in a middle school. Master Dissertation, Pacific Lutheran University.

Çoban, S. (1999). Yöneticilerin yaratıcılı düzeyleri ile liderlik tarzları arasındaki ilişki [Relationship between creativity levels and leadership styles of managers]. Yayinlanmamış doktora tezi, İstanbul Üniversitesi Sosyal Bilimleri Enstitüsü, İstanbul. 
Dennis, J., \& O’Hair, M. J. (2010). Overcoming obstacles in using authentic instruction: A comparative case study of high school math and science tearchers. American Secondary Education, 38(2), 4-22.

Garner, S. (2003, June). Learning resources and tools to aid novices learn programming. Paper presented at Proceedings of Informing Science \& Information Technology Education Joint Conference, Pori, Finland. http://citeseerx.ist.psu.edu/viewdoc/ download?doi=10.1.1.3.1909\&rep=rep1\&type=pdf

Gatlin, L., \& Edwards, R. (2007). Promoting authentic learning through a peaceful and positive perspective. Journal of Authentic Learning, 4(1), 1-8.

Giray, S. (2016). İki aşamalı kümeleme analizi ile hükümlü verilerinin incelenmesi [Investigation of convict data by two stage cluster analysis]. Ekonometri ve Istatistik [Econometrics and statistics], 25, 1-31.

Gleeson, A. M. (2011). Preparing teachers and students for semocracy: Teacher and student learning and authentic intellectual work. Doctoral Dissertation, Boston College, USA.

Goold, A., \& Rimmer, R. (2000). Indicators of performance in first-year computing. Paper presented at Computer Science Conference, 2000. ACSC 2000. 23 $3^{\text {rd }}$ Australasian (pp. 74-80). IEEE. https://www.researchgate.net/publication/3837359_ Indicators_of_performance_in_first-year_computing

Göçmen, G. B. (2004, Temmuz). Otantik değerlendirme nedir ve nasıl yapılır? [What is an authentic assessment and how is it done?] Paper presented at XIII. Ulusal Eğitim Bilimleri Kurultayı, İnönü Üniversitesi, Eğitim Fakültesi, Malatya. https://www. pegem.net/dosyalar/dokuman/410.pdf

Grover, S., Pea, R., \& Cooper, S. (2015). Designing for deeper learning in a blended computer science course for middle school students. Computer Science Education, $25(2), 199-237$.

Gündoğan, A., \& Gültekin, M. (2018). The reflection of the attitudes and learning processes to learning environments with authentic tasks in life science class. Pegem Ĕ̈itim ve Öğretim Dergisi [Pegem Journal of Education and Training ], 8(4), 771832.

Heasly, B., Lindner, J., Iliško, Dz., \& Salīte, I. (2020). From initiatives, to insights, to implementation of the sustainability and securitability agenda for 2030. Discourse and Communication for Sustainable Education, 11(1), 1-4.

Herrington, J., \& Oliver, R. (2000). An instructional design framework for authentic learning environments. Educational Technology Research and Development, 48(3), 23-48.

Horzum, M. B., \& Bektaş, M. (2012). Otantik öğrenmenin topluma hizmet uygulamaları dersini alan öğretmen adaylarının derse yönelik tutum ve memnuniyetine etkisi [The effect of authentic learning on preservice teachers' attitude and satisfaction towards service learning]. Kastamonu Eğitim Dergisi, 20(1), 341-360.

Hussain, S., Ahmad, N., \& Khan, F. N. (2015). The effects of authentic pedagogical practices on students' educatinal performances and retention power. Pakistan Journal of Education, 30(2), 47-62.

Iucu, R. B., \& Marin, E. (2014). Authentic learning in adult education. Procedia Social and Behavioral Sciences, 142, 410-415.

Johnson, Y. L. (2007). The efficacy of authentic assessment versus pencil and paper testing in evaluating student achievement in a basic technology Course. Doctoral Dissertation, Walden University. 
Kinay, İ., \& Bağçeci, B. (2015). Otantik değerlendirme sürecine katılan öğretmen adaylarinin duyuşsal özelliklerinin incelenmesi [Investigation of emotional features of prospective teachers participated in the process of authentic assessment]. Eğitim ve Insani Bilimler Dergisi: Teori ve Uygulama [Journal of Education and Humanities: Theory and Practice], 6(12), 67-80.

Koçyiğit, S. (2011). Otantik görev odaklı yapılandırmact yaklaşımın öğretmen adaylanıın başarılarına, derse karşı tutumlarına ve problem çözme becerilerine etkisi [The effects of the authentic task based constructivist approach on preservice teachers? Achievement, attitudes towards classes and problem solving skills]. Yayımlanmamış doktora tezi, Marmara Üniversitesi, Eğitim Bilimleri Enstitüsü, İstanbul.

Koçyiğit, S., \& Zembat, R. (2013). Otantik görevlerin öğretmen adaylarinin başarilarina etkisi [The effects of the authentic task on preservice teachers' achievement]. Hacettepe Üniversitesi Eğitim Fakültesi Dergisi, 28(3), 291-303.

Mintah, J. K. (2009). Authentic assessment in physical education: Prevalence of use and perceived impact on students' self-concept, motivation, and skill achievement. Measurement in Physical Education and Exercise Science, 7(3), 161-174.

Newmann, F. M., Marks, H. M., \& Gamoran, A. (1995). Authentic pedagogy: Standards that boost student performance. Issues in Restructuring Schools, 1-17.

Newmann, F. M., Marks, H. M., \& Gamoran, A. (1996). Authentic pedagogy and student performance. American Journal of Education, 104, 280-312.

Newmann, F. M., \& Wehlage, G. G. (1993). Five standards of authentic instruction. Educational Leadership: Journal of the Department of Supervision and Curriculum Development, 50(7), 8-12.

Niesz, T. M. (2003). The project approach to learning: How the project approach provides opportunities for authentic Learning. Master Dissertation, Pacific Lutheran University.

Preus, B. (2012). Authentic instruction for $21^{\text {st }}$ century learning: Higher order thinking in an inclusive school. American Secondary Education, 40(3), 59-79.

Purcell-Gates, V., Duke, N., \& Martineau, J. A. (2011). Learning to read and write genre-specific text: Roles of authentic experience and explicit teaching. Reading Research Quarterly, 42(1), 8-45.

Reed, L. (1993). Achieving the aims and purposes of schooling through authentic assessment. Middle School Journal, 25(2), 11-13.

Renzulli, J. S., Gentry, M., \& Reis, S. M. (2004). A time and a place for authentic learning. Educational Leadership, 62(1), 73-77.

Robinson, K. (2003). Yaratıcılık aklın sınırların aşmak [Creativity transcends the limits of the mind]. İstanbul, Kitap Publisher.

Rule, A. (2006). The components of authentic learning. Journal of Authentic Learning, $3(1), 1-10$.

Šlahova, A., Volonte, I., \& Čačka, M. (2017). Interrelations in the development of primary school learners' creative imagination and creative activity when depicting a portrait in visual art lessons. Discourse and Communication for Sustainable Education, 8(1), 102-120.

Sönmez, V., \& Alacapınar, F. G. (2014). Örneklendirilmiş bilimsel araştırma yöntemleri (Genişletilmiş 3.Baskı) [Exemplified scientific research methods]. Ankara, Anı Publisher.

Şahin, N., Şahin, N. H., \& Heppner, P. P. (1993). The psychometric properties of the problem solving inventory. Cognitive Therapy and Research, 17, 379-396. 
Taranto, D., \& Buchanan, M. T. (2020). Sustaining lifelong learning: A self-regulated learning (SRL) approach. Discourse and Communication for Sustainable Education, 11(1), 5-15.

Tillmanns, T., Holland, C., \& Filho, A. S. (2017). Design criteria for visual cues used in disruptive learning interventions within sustainability education. Discourse and Communication for Sustainable Education, 8(2), 5-16.

Uçar, N. (2008). Kümeleme analizi [Cluster analysis], Şeref Kalaycı (Ed.). Spss uygulamal çok değişkenli istatistik teknikleri [SPSS applied multivariate statistical techniques]. Ankara, Asil Yayın Dağıtım, 350-369.

Vatansever, F. (2007). Algoritma geliştirme ve programlamaya giriş [Introduction to algorithm development and programming]. Ankara, Seçkin Publisher.

White, J. (2008). Sustainable pedagogy: A research narrative about performativity, teachers and possibility. Transnational Curriculum Inquiry, 5(1), 1-14.

Yaşar, E. (2012). Algortima ve programlama giriş [Algorithm and programming introduction]. Trabzon, Murathan Publisher.

Young, M. F. (1993). Instructional design for situated learning. Educational Technology Research and Development, 41(1), 43-58.

Correspondence concerning this paper should be addressed to Assist. Prof. Dr. Emine Kübra Pullu, Turkey, Munzur University, Çemişgezek Vocational School. Email: ekubrafidan@gmail.com 